\title{
Risiko dan Peluang Industri Makanan Rumah Tangga dengan Sistem On-Line dalam Masa Pandemi Covid-19 di DIY
}

\author{
Rachmawati Widyaningrum $^{\mathrm{a}, 1, *}$, Khairunisa Ramadhani ${ }^{\mathrm{b}, 2}$, Hesti Khofifah ${ }^{\mathrm{c}, 3}$, Shaumi \\ Natalia Putri ${ }^{\mathrm{d}, 4}$ \\ a,b,c,d Fak. Kesehatan Masyarakat UAD, Jl. Prof. DR. Soepomo Sh, Warungboto, Umbulharjo, Yogyakarta, 55164 \\ Indonesia \\ ${ }^{1}$ Rachmawati.widyaningrum@ @izi.uad.ac.id *; ${ }^{2}$ Khairunisa.ramadhani@ gizi.uad.ac.id; \\ hesti2000036138@webmail.uad.ac.id; ${ }^{3}$ shaumi2000036072@webmail.uad.ac.id \\ * penulis korespondensi
}

\begin{abstract}
During pandemic Covid-19, the online delivery and ordering system in the household food industry is an alternative for fulfilling the consumer's food requirement without leaving their house. Further, the household food industry also works as a national economic trigger. However, concern about food safety, virus transmission, and halal-food status is still challenging with the low number of the household food industry that has been registered and has a halal certificate. This study aimed to understand the perceptions of the stakeholder of the online selling system of the household food industry the pandemic of Covid-19 due to: 1) Risk of product's safety and Halal status 2) Economic opportunity 3) Management system to minimize risk and optimize the opportunity. The research was a descriptive qualitative study conducted through an online interview held in January-February 2021. Respondents are the household food industry's producers in DIY, conducting commercial household food production during the pandemic, doing online selling, and did not have an offline store. The subjects were recruited using the purposive sampling method. Data triangulation was applied using a deep interview with consumers, food safety, and halal food expert. In total, 8 respondents participated in this study. The household food industry during pandemic brings a positive effect on the household's economic strengthening and entrepreneur opportunity. Food safety and halal food issues arise from a lack of knowledge of the producer, resource limitation, and uncertified products. These risks could be minimized through sustainable collaboration between producers, consumers, and the government for actualizing halal and safe food production.
\end{abstract}

Keywords: Covid-19 Outbreak, Food Safety, Halal Food, Household Food Industry

\begin{abstract}
ABSTRAK
Dalam masa pandemi Covid-19, sistem pemesanan dan pengantaran online pada industri makanan rumah tangga merupakan sebuah alternatif untuk memenuhi kebutuhan pangan konsumen tanpa harus keluar rumah sekaligus sebagai penggerak ekonomi nasional. Namun demikian, isu keamanan pangan, risiko transmisi virus, dan kehalalan makanan masih menjadi tantangan dalam menjalankan bisnis tersebut dengan banyaknya produk industri makanan rumah tangga yang belum beregistrasi dan bersertifikasi halal. Penelitian ini bertujuan mengkaji tentang bagaimana persepsi stakeholder industri makanan rumah tangga dengan sistem online di masa pandemi Covid-19 terkait: 1) Risiko kesehatan dan kehalalan produk 2) Peluang ekonomi bisnis makanan online 3) Praktik pengelolaan bisnis makanan untuk meminimalisasi risiko dan memaksimalkan peluang penjualan makanan secara online. Penelitian ini adalah penelitian kualitatif dengan desain deskriptif yang dilaksanakan melalui wawancara online pada bulan Januari-Februari di DIY. Responden adalah produsen makanan di DIY, menyelenggarakan produksi makanan komersial skala rumah tangga selama pandemi, melaksanakan sistem penjualan makanan secara online, dan
\end{abstract}


tidak memiliki toko offline. Pengumpulan data dilakukan dengan metode purposive sampling. Metode triangulasi dilakukan dengan melakukan wawancara kepada ahli keamanan dan kehalalan pangan dan konsumen industri makanan rumahan dengan total jumlah responden 8 orang. Industri makanan skala rumah tangga dalam masa pandemi Covid-19 memberikan dampak positif pada penguatan ekonomi rumah tangga dan peluang usaha. Risiko keamanan dan kehalalan pangan muncul dari minimnya pengetahuan produsen tentang keamanan dan kehalalan pangan, keterbatasan sumber daya, serta produk yang dihasilkan belum tersertifikasi. Risiko tersebut dapat diminimalkan dengan kolaborasi antara produsen, konsumen dan pemerintah untuk mewujudkan pangan yang aman dan halal.

Kata Kunci: Industri Makanan Rumah Tangga, Keamanan Pangan, Pandemi Covid-19, Pangan Halal

\section{Pendahuluan}

Perkembangan teknologi dalam bentuk tersedianya koneksi internet telah merubah cara konsumen membeli makanan. Proses adopsi teknologi dalam bisnis makanan telah memfasilitasi munculnya sistem pemesanan dan pengantaran makanan secara daring (online) melalu berbagai pasar daring (marketplace), aplikasi agregator makanan, pengantaran restoran, dan media sosial. Di Indonesia, menurut data Badan Pusat Statistik tahun 2019, jasa pesan antar makanan secara daring tersebut setiap tahunnya diperkirakan tumbuh hingga mencapai 11,5\% (2020-2024). Lebih lanjut, kategori makanan menyumbang proporsi terbesar dari semua kategori e-commerce dengan kontribusi sebesar 27,85\% (Aprilianti \& Amanta, 2020).

Adanya sistem pemesanan dan pengantaran makanan daring tersebut menjadi sangat krusial pada masa pandemi Covid-19. Sebuah studi di China menunjukkan, meskipun pendapatan bisnis katering pada awal pandemi menurun drastis, namun kondisi tersebut kembali membaik dengan adanya penyesuaian pelaku bisnis untuk berubah dari sistem offline tradisional yang bergeser ke sistem daring melalui aplikasi pengantaran makanan. Kondisi ini bukan hanya memenuhi kepentingan produsen makanan, namun juga memenuhi kebutuhan konsumen untuk mendapatkan pasokan makanan secara aman (Zhao \& Bacao, 2020).

Sektor usaha makanan dan minuman tersebut akan terus tumbuh mengingat kuatnya permintaan pasar dalam negeri. Meskipun bisnis makanan tersebut termasuk dalam Usaha Mikro, Kecil, dan Menengah (UMKM), namun memiliki kontribusi yang sangat besar bagi perekonomian Indonesia. Bisnis UMKM ini akan mampu bertahan dalam kondisi pandemi dengan perlindungan dan pemulihan, serta peningkatan kreasi dan inovasi, temasuk didalamnya pengembangan layanan online dalam memasarkan produknya (Putra et al., 2020 dan Sugiri, 2020).

Namun demikian, produksi makanan skala rumah tangga secara online juga memiliki beberapa risiko, termasuk di antaranya risiko keamanan pangan. Sistem perdagangan online ini secara tidak langsung membuat pelaku bisnis makanan dapat menjual produk secara bebas dan dengan mudah mendapatkan atensi pasar. Sedangkan dalam studi Nurcahyo (2018) dalam Pritanova P et al. (2020), menyatakan bahwa kesadaran pelaku UMKM untuk menerapkan standar keamanan pangan pada produk yang dijualnya masih dianggap rendah. Berdasarkan data BPOM tahun 2017, dari 2352 Industri Rumah Tangga 
Pangan (IRTP) hanya 10,7\% yang telah melakukan Cara Produksi Pangan Olahan yang Baik (CPPOB).

Sebuah studi oleh Manayang et al. (2018), dalam pembahasannya menjelaskan bahwa pada proses produksi industri makanan rumah tangga terdapat beberapa aspek yang tidak memenuhi syarat kebersihan antara lain tidak menggunakan Alat Pelindung Diri (APD), pengolah makanan tidak menjaga kebersihan diri, menggaruk anggota tubuh, dan mengunyah makanan saat bekerja yang meningkatkan kontaminasi bakteri E.coli. Dalam konteks Covid-19, meskipun sampai saat ini belum ada laporan bahwa SARS-CoV-2 ditularkan melalui konsumsi makanan, namun rekomendasi protokol kebersihan tetap harus diinformasikan kepada produsen pangan untuk pencegahan transmisi virus melalui rantai pangan. Disamping itu, konsumen juga harus menerapkan protokol kesehatan saat berbelanja atau mengolah makanan (WHO \& FAO, 2020).

Selain isu keamanan pangan, sebagai negara dengan populasi muslim tertinggi, kebutuhan makanan halal juga menjadi tantangan untuk dipenuhi (Yunita, 2018). Kehalalan suatu makanan ditentukan berdasar sebuah hukum kehalalan pangan yang menentukan apakah makanan tersebut telah memenuhi syarat hukum dan diperbolehkan untuk dikonsumsi umat muslim. Adanya inovasi dalam penyembelihan hewan, pengolahan daging, sumber bahan pangan non-konvensional, dan material sintesis menjadi sebuah tantangan untuk memastikan pembeli mendapatkan informasi kehalalan pangan sebelum mengambil keputusan untuk membeli produk (Chaudry \& Riaz, 2014).

Aspek halal dalam produk makanan tersebut meliputi bahan utama, bahan campuran, dan proses produksi hingga ke tangan konsumen. Kejelasan status halal tersebut sangat penting sehingga terdapat sebuah proses khusus untuk memastikan kehalalan sebuah produk melalui sertifikasi halal yang dilaksanakan oleh Lembaga Pengkajian Pangan Obatobatan dan Kosmetika Majelis Ulama Indonesia (LPPOM MUI) (Akim et al., 2018). Dalam proses penentuan kehalalan makanan tersebut juga akan diambil contoh pada titiktitik kritis yang berpotensi atau terindikasi menggandung babi dan turunannya, alkohol dan turunannya, dan bahan lain yang berisiko (Farhan, 2019).

Penelitian sebelumnya oleh Akim et al. (2018) yang mempelajari pemahaman UMKM tentang produk halal juga menemukan bahwa pemahaman masyarakat dan produsen makanan di Indonesia tentang pentingnya makanan halal masih rendah. Permasalahan tersebut terletak pada anggapan bahwa mayoritas masyarakat di Indonesia adalah muslim, sehingga semua produk yang diperdagangkan oleh orang muslim adalah halal. Pemahaman tersebut menjadi dasar bagi para produsen untuk tidak perlu melakukan sertifikasi halal.

Lebih lanjut, meskipun telah ada penelitian terdahulu tentang kehalalan produk pangan UMKM (Akim et al., 2018) dan tentang keamanan pangan produk UMKM (Aprilianti \& Amanta, 2020), namun belum ada penelitian yang mengkaji secara komprehensif tentang risiko kesehatan, kehalalan produk, dan peluang ekonomi bagi bisnis makanan online skala rumah tangga pada masa Covid-19, khususnya di DIY. Berdasarkan latar belakang diatas, serta profil Provinsi DIY yang memiliki banyak UKM bidang kuliner, maka peneliti bermaksud meneliti tentang bagaimana persepsi pemangku kepentingan bisnis makanan online skala rumah tangga di masa pandemi Covid-19 terkait: 1) Risiko kesehatan dan kehalalan produk 2) Peluang ekonomi bisnis makanan online 3) Praktik pengelolaan bisnis 
makanan untuk meminimalisasi risiko dan memaksimalkan peluang penjualan makanan secara online.

Hasil penelitian ini diharapkan dapat menjadi gambaran dan tambahan informasi bagi pemangku kepentingan dalam industri jasa makanan tentang strategi UMKM pangan yang dapat diterapkan dalam meminimalkan resiko yang dihadapi dan optimalisasi potensi UMKM pangan pada masa pandemi Covid-19.

\section{Metode Penelitian}

Penelitian ini merupakan penelitian kualitatif dengan desain deskriptif. Responden dari kelompok produsen makanan rumah tangga ditentukan dengan kriteria inklusi: Tinggal di DIY, menyelenggarakan produksi makanan komersial skala rumah tangga selama pandemi, melaksanakan sistem penjualan makanan secara online, dan tidak memiliki toko offline. Pengumpulan data dilakukan dengan metode purposive sampling dan metode triangulasi dilakukan dengan melakukan wawancara kepada ahli keamanan dan kehalalan pangan, serta konsumen on-line industri makanan rumahan.

Penelitian dilaksanakan pada bulan Januari-Februari 2021 melalui wawancara mendalam menggunakan platform meeting online dikarenakan pertimbangan keamanan dalam masa pandemi Covid-19. Sebelum wawancara responden akan dijelaskan mengenai prosedur penelitian dan diberikan lembar persetujuan setelah penjelasan (Informed Consent) dalam bentuk file yang dapat dibubuhkan tanda tangan digital jika responden menyetujui untuk berpartisipasi.

\section{Hasil dan Pembahasan}

\subsection{Karakteristik responden}

Secara keseluruhan terdapat 8 responden yang berpartisipasi dalam studi ini. Responden paling banyak adalah pelaku usaha (50\%), sedangkan 2 responden lain adalah konsumen, 1 responden adalah representasi dari institusi yang bertanggung jawab pada keamanan pangan, dan 1 responden dari institusi yang bertanggung jawab pada kehalalan pangan.

Pelaku usaha yang diwawancara merupakan 4 produsen pangan skala rumah tangga yang memasarkan produk secara murni on-line (tidak memiliki toko offline). Dua responden memiliki spesifikasi produk pangan camilan (Snack and dessert) dan satu responden memiliki spesifikasi produksi baik camilan dan makanan berat, dan satu produsen memproduksi lauk.

\subsection{Persepsi tentang perkembangan bisnis makanan skala rumah tangga dengan sistem online di masa pandemi Covid-19}

Secara umum, responden berpendapat bahwa bisnis makanan online ini sudah ada sejak sebelum pandemi Covid-19 terjadi, dan jumlahnya meningkat selama masa pandemi. Dari sisi konsumen, konsumen merasa sangat terbantu dengan adanya sistem pemesanan makanan daring ini, terlebih saat pandemi para konsumen harus mengurangi aktivitas di luar rumah.

"Kalo untuk bisnis makanan online ya, saya lihat semakin rame, apalagi sejak pandemi ya. Jadi yang sebelumnya nggak punya jualan online, terus shifting jadi buka, buka kedai online gitu ya. Karena kan kalau bagi saya sendiri sangat membantu sih.." -R.Konsumen- 
"Nah, semenjak covid lebih jadi lebih sering (pesan) kayanya."-A.Konsumen-

Sistem pemasaran daring yang diterapkan oleh pelaku usaha adalah dengan memanfaatkan sosial media, reseller online, dan applikasi agregator makanan, namun sistem pemasaran yang paling banyak diterapkana adalah dengan sosial media. Untuk sistem pengantaran umumnya dilakukan dengan Cash on Delivery (COD) oleh produsen langsung, dengan jasa antar aplikasi agregator makanan, dan kurir personal. Produsen umumnya sudah memiliki pelanggan tetap contohnya seperti konsumen di kantor-kantor dan juga pelanggan individual.

"Kantoran gitu, jadi di kantor mereka barengan terus ngirimnya jadi sekalian." E.Produsen-

\subsection{Persepsi tentang peluang ekonomi bisnis makanan skala rumah tangga dengan sistem online di masa pandemi Covid-19}

Selama pandemi, terdapat perubahan sistem penjualan dari sistem offline. Perubahan ini secara jumlah konsumen offline menjadi menurun, namun konsumen online meningkat.

“... Karena konsumennya yang berkurang, tapi ada juga konsumen baru juga sih sebenernya, jadi lebih kehilangan yang offlinenya itu sih, kalo ada offline nya lebih bisa lagi. Tapi yang baru-baru juga ada sih sebenernya kalau dari segi penjualan sebenernya bertambah ya kalau dari yang dulu......" -E. Produsen-

Tantangan produksi dirasakan pada awal pandemi ketika bahan baku sulit didapatkan dan harga naik, namun seiring pembatasan sosial mulai dilonggarkan, bahan-bahan tersedia seperti biasa. Keuntungan yang didapatkan juga tidak berubah secara signifikan dengan adanya fluktuasi harga bahan.

Secara umum, baik produsen, konsumen, dan ahli keamanan dan kehalalan pangan memiliki pendapat yang sama bahwa saat pandemi ini bisnis makanan skala rumah tangga memiliki peluang ekonomi yang baik dan dapat menunjang ekonomi pada tingkat rumah tangga. Selain itu, bisnis online ini juga mendukung pemberdayaan masyarakat dengan melibatkan tetangga atau kerabat dalam rantai bisnis makanan ini, contohnya sebagai penyedia bahan baku.

\subsection{Persepsi tentang risiko kesehatan bisnis makanan skala rumah tangga dengan sistem online di masa pandemi Covid-19}

Berdasarkan hasil analisis, dari sisi produsen, kriteria pangan yang aman adalah makanan yang bahan bakunya terjamin kualitasnya, bahannya dicuci bersih, makanan yang matang (telah diolah), dan dikemas dengan baik.

Terkait penggunaan alat pelindung diri, secara umum produsen berpendapat bahwa mencuci tangan dengan bersih sudah cukup untuk melindungi kontaminasi, sehingga tidak diperlukan penggunaan sarung tangan. Selain itu sarung tangan dirasa membuat produsen tidak nyaman saat mengolah makanan.

"Iya, tapi kalau dalam pembuatan yang penting kan cuci tangan, cuci tangan bersih pakai sabun seperti itu, he-eh. Sarung tangan ada di rumah, tapi kalau memakai sarung tangan itu kerjaannya emang agak ini ya. Mungkin karena gak terbiasa, tapi saya selalu cuci tangan pakai sabun." -D.Produsen- 
Dari sisi konsumen, konsumen merasa bahwa makanan yang dijual oleh orang yang dikenal dan telah masuk dalam aplikasi agregator makanan lebih aman. Baik konsumen dan produsen berpendapat bahwa indikator pangan yang aman dilihat dari ada tidaknya komplain terhadap makanan tersebut, jika makanan diterima dalam kondisi baik dan layak makan maka dianggap sebagai makanan yang aman. Namun demikian, berdasarkan persepsi ahli keamanan pangan, pangan tidak hanya dilihat dari tampilan dan kondisi fisik produk makanan, tetapi juga harus melalui uji laboratorium.

Secara umum produsen memberikan tanggapan yang positif terkait izin produksi makanan atau penerbitan surat Sertifikat Produksi Pangan Industri Rumah Tangga (SPPIRT). Namun demikian terdapat beberapa pertimbangan yang membuat para produsen merasa membuat PIRT itu sulit yaitu untuk dapur masih jadi satu dengan dapur rumah tangga, proses birokrasi, dan ada kekhawatiran diminta untuk membayar.

\subsection{Persepsi tentang risiko kehalalan produk bisnis makanan skala rumah tangga dengan sistem online di masa pandemi Covid-19}

Produsen merasa telah mengusahakan produk yang diproduksi halal dengan cara memilih penyedia bahan mentah yang terjamin halal, seperti tempat pemotongan ayam halal. Selain itu produsen juga menghindari pemakaian bahan baku kemasan curah, harus yang bermerek.

Risiko kehalalan produk muncul dengan pemahaman sebagian produsen namun sebagian merasa bahwa produk yang memiliki kode BPOM dapat disamakan dengan produk halal, meskipun beberapa produsen lain memilih produk yang berlogo halal. Produsen juga merasa produk repack merupakan salah satu risiko ketidakhalalan produk. Selain itu, beberapa produsen juga mengambil bahan setengah jadi untuk diolah atau dikemas kembali yang berisiko tidak halal, misal bakso.

Sejalan dengan pernyataan dari pakar halal yang mengungkapkan bahwa sebenarnya produsen sudah mengerti bahwa apa yang mereka kerjakan jika diajukan untuk proses sertifikasi halal akan menjadi sebuah temuan. Sehingga produsen merasa tidak cukup percaya diri untuk membuat sertifikasi jaminan halal pada produk olahan mereka. Selain itu, satu hal yang membuat produsen tidak mengurus sertifikasi jaminan halal adalah karena terkendala dana, dimana para produsen memahami bahwa pengurusan sertifikasi jaminan halal itu mahal.

"Berarti kan sebenernya mereka udah tau, jadi ketika apa namanya ketika mereka sudah tau, mereka sadar betul bahwa ini tuh belum memenuhi syarat makanya dia belum berani untuk mengajukan,............. untuk bisa merubah itu mereka butuh "pendanaan" nah mungkin karena mereka belum siap sampai ke ranah pendanaan itu makanya dia tidak pede-lah untuk maju'.-R. Pakar Halal

Pakar halal pun mengungkapkan bahwa para pelaku bisnis UMKM masih beranggapan bahwa ketika mereka membuat sertifikasi jaminan halal pada produk mereka itu hanya sebuah kebutuhan. Pembuatan sertifikasi jaminan halal itu hanya dianggap sebuah syarat sah pada produk mereka. Disisi lain pakar halal menyayangkan jika pelaku usaha UMKM hanya melihat itu sebagai kebutuhan, karena jika produsen melihat dari sisi peluang, maka pembuatan sertifikasi halal tersebut akan membuka peluang keuntungan yang lebih besar. 
"UMKM kita itu masih melihat bahwa sertifikasi jaminan halal itu masih sebatas sebagai kebutuhan jadi ya peluang atau tantangan. Peluang atau tantangan itu misalkan apa namanya ee di bahasakan necessity or opportunity, jadi masih banyak melihat itu tu sebagai sebuah kebutuhan. Jadi kayak cuman syarat sahnya begitu”. -R. Pakar Halal

\subsection{Persepsi tentang manajemen risiko dan optimalisasi peluang ekonomi bisnis makanan skala rumah tangga dengan sistem online di masa pandemi Covid-19}

Menurut persepsi produsen, penjualan dapat terus ditingkatkan dengan inovasi produk baru dan peningkatan kualitas makanan (sebagai contoh uji coba resep baru yang menghasilkan produk yang lebih baik), serta memperluas pasar. Promosi umumnya dilakukan dengan cara pemberian sampel produk baru atau memberikan ekstra produk kepada konsumen. Sebagian besar produsen tidak memilih promosi berupa diskon produk karena merasa bahwa keuntungan produknya tidak cukup banyak untuk memberikan diskon.

Produsen mengoptimalkan pendapatan dengan menyesuaikan tipe pemesanan makanan pada sistem online ini, sebagian produsen menggunakan sistem pre-order $(P O)$ untuk dan sebagian lagi berproduksi rutin harian dengan jumlah tertentu. Produsen yang memproduksi makanan basah siap makan dan memiliki variasi menu yang beragam cenderung memilih sistem PO untuk meminimalisasi sisa produksi. Sedangkan produsen yang memproduksi makanan kering atau produknya spesifik cenderung memproduksi secara rutin karena produknya dapat bertahan beberapa hari.

Peluang bisnis masih terbuka berdasarkan pendapat konsumen bahwa konsumen merasa membutuhkan layanan bisnis makanan online yang memberikan pilihan yang luas kepada konsumen untuk memilih makanan sesuai keinginan konsumen. Konsumen memiliki preferensi pemilihan produsen berdasar kedekatan personal (teman atau kerabat) atau melihat rating jika menggunakan aplikasi agregator makanan. Selain itu konsumen umumnya akan menjadi pelanggan tetap jika kualitas rasa terjamin dan memiliki peluang besar untuk melakukan pemesanan berulang.

"Iya kalau aku kan pasti kenal orangnya. Aku percaya gitu loh, percaya pasti terjamin lah kayak gitu, kalau yang go-jek kaya gitu, udah pakai go-jek kan aku anggap apa warungnya sudah disurvei sama gojeknya gitu kan. Iya kan? Lolos dari go-jek atau grabnya berarti kan dia sudah lolos quality control dari sana.." -A.Responden Konsumen-

"Oh dilihat, terus sama diliat ratingnya, ratingnya berapa gitu kan,...tapi biasanya kaya paling nggak 4,5 keatas lah. Itu seharusnya ngga zonk-zonk banget gitu” R.Responden Konsumen-

Adapun risiko adanya komplain dari konsumen, produsen berpendapat bahwa komplain dapat diselesaikan dengan cara menanggapi komplain dengan baik dengan cara menukar dengan barang baru dan menggratiskan produk yang di komplain. Hal ini sejalan dengan persepsi konsumen bahwa konsumen akan merasa puas jika komplainya ditanggapi dengan baik, dan jika ditanggapi dengan baik konsumen akan tetap menjadi pelanggan. Sebaliknya, jika komplain tidak ditanggapi dengan baik, hal tersebut menjadi alasan bagi konsumen untuk tidak melakukan pembelian ulang pada produsen tersebut.

Dari segi ahli keamanan pangan, peluang usaha harus tetap diambil oleh masyarakat. Sedangkan risiko keamanan pangan yang dihadapi dapat diminimalisasi dengan 
mengoptimalkan peran 3 pilar keamanan pangan, yaitu produsen yang memproduksi pangan yang aman, pemerintah yang melakukan fungsi regulasi dan pengawasan, serta peran aktif masyarakat untuk memilih produk yang aman.

Menurut penuturan dari pakar kehalalan bahwa UMKM tetap diharapkan memproses SJH karena memiliki potensi berupa peningkatan keuntungan pada produk yang mereka jual, selain itu pakar menguangkapkan bahwa pembuatan SJH dapat meningkatkan kepercayaan konsumen terhadap produk yang mereka jual.

"Sosialsisasi itu penting bagaimana eee istilahnya memberikan gambaran kepada mereka bahwa SJH ini tidak hanya sekedar wajib, tapi SJH ini juga buka peluang mereka untuk bisa memberikan keuntungan lebih, nah itu sebenernya point utamanya disitu.-R. Pakar Halal

Pakar halal dari halal center memberikan solusi untuk memudahkan para pelaku bisnis UMKM dalam memproses pembuatan sertifikasi jaminan halal pada produk mereka. Para pelaku usaha UMKM bisa membuat sebuah kelompok yang dimana lokasi tempat produksi mereka bisa dalam satu area tempat yang sama. Upaya pendampingan kepada UMKM, dan pemberian materi edukasi pun dilakukan untuk mempermudah proses pembuatan sertifikasi jaminan halal. Kegiatan tersebut dapat terlaksana jika para produsen memiliki keinginan serta attitude untuk menjamin produk yang di jual kepada konsumen adalah halal.

"Jadi kalo dari beberapa solusi yang ditawarkan mungkin ada yang eee beberapa mereka yang bisa semacam membikin gruping gitu mbak”. R-Pakar Halal

\subsection{Pembahasan}

Dalam masa pandemi Covid-19 ini, industri makanan skala rumah tangga yang dipasarkan secara online menawarkan dua keuntungan, selain memberikan kemudahan bagi konsumen untuk memilih dan membeli makanan tanpa perlu keluar rumah dalam rangka pencegahan transmisi virus, sistem ini juga memberdayakan ekonomi dalam lingkup rumah tangga, dan bahkan dapat memberdayakan lingkungan sekitarnya. Selain itu, hasil penelitian juga menunjukkan respon positif baik dari produsen, konsumen, maupun pemangku kepentingan di pemerintahan. Dalam situasi dimana ekonomi terganggu akibat pandemi, sektor bisnis ini tetap memberikan peluang dan pendapatan yang menguatkan ekonomi rumah tangga. Hal tersebut sesuai pernyataan Aprilianti \& Amanta (2020) yang menyebutkan bahwa pesan antar makanan daring memperluas pilihan dan kenyamanan konsumen dalam memilih makanan, membuka lapangan kerja dan wirausaha termasuk para pedagang mikro dan kecil, disamping kontribusinya yang besar pada perekonomian Indonesia.

Dalam menjalankan bisnis online, produsen lebih memilih menggunakan media sosial. Menurut Achmad et al. (2020), media sosial memang sangat diminati UMKM dalam pengembangan bisnis dikarenakan pengaruhnya yang besar dan mempercepat informasi diterima masyarakat. Hal tersebut menyebabkan pengusaha kecil UMKM lebih berani mempromosikan produknya dengan lebih luas, tidak ada Batasan waktu, serta wilayah yang menjadikan media sosial menjedi media pemasaran yang efektif.

Meskipun demikian, beberapa risiko tetap harus dipertimbangkan dalam bentuk risiko keamanan dan risiko kehalalan pangan. Dalam hal keamanan pangan masih terdapat 
beberapa aspek yang belum dipahami secara menyeluruh oleh produsen tentang kriteria makanan yang aman, meskipun produsen telah berusaha mengupayakan agar produk yang di produksi aman. Salah satu risiko keamanan pangan yang ditemukan adalah penggunaan APD yang tidak lengkap yang sesuai dengan penelitian Manayang et al. (2018), bahwa pada proses produksi industri makanan rumah tangga terdapat beberapa aspek yang tidak memenuhi syarat kebersihan antara lain tidak menggunakan Alat Pelindung Diri (APD).

Menurut Peraturan Kepala Badan Pengawas Obat dan Makanan Republik Indonesia (Perka BPOM) nomor 03.1.23.04.12.2206 tahun 2012 tentang cara produksi pangan yang baik untuk industri rumah tangga (CPPB- IRT), menjelaskan bahwa CPPB- IRT adalah faktor penting dalam memenuhi standar mutu keamanan pangan. CPPB- IRT ini digunakan untuk industri pangan dari skala kecil hingga skala besar. Dengan adanya CPPB- IRT ini diyakini bahwa industri pangan akan menghasilkan pangan yang bermutu baik, aman untuk kesehatan, serta layak untuk dikonsumsi. Hal tersebut akan meningkatkan kepercayaan masyarakat terhadap produk di industri pangan tingkat rumah tangga, melindungi masyarakat dari penyimpangan mutu pangan, dan ancama bahaya kesehatan. Untuk mengajukan CPPB- IRT, produsen harus memenuhi syarat-syarat yang mencakup 14 aspek yaitu: lokasi dan lingkungan produksi, bangunan dan fasilitas, peralatan produksi, suplai air atau sarana penyediaan air, fasilitas dan kegiatan higiene dan sanitasi, kesehatan dan higiene karyawan, pemeliharaan dan program higiene sanitasi karyawan, penyimpanan, pengendalian proses, pelabelan pangan, pengawasan oleh penanggungjawab, penarikan produk, pencatatan dan dokumentasi, dan pelatihan karyawan.

Selain itu, baik konsumen dan produsen berpendapat bahwa makanan yang aman adalah makanan yang dalam kondisi baik yaitu tidak menunjukkan tanda-tanda rusak dan tidak ada cemaran fisik. Menurut Lestari (2015), pangan yang tidak aman memang dapat dideteksi dengan tanda-tanda misalnya bau busuk, tengik atau adanya kotoran. Namun ada juga risiko tidak kasat mata yang membahayakan kesehatan seperti bakteri, virus, dan bahan kimia tidak layak konsumsi.

Di Indonesia, sertifikasi jaminan halal pada suatu produk yang diproduksi oleh UMKM dikeluarkan oleh suatu lembaga yang dikenal dengan LPPOM MUI. Label sertifikasi halal pada suatu produk pangan UMKM secara tidak langsung akan membuat konsumen menjadi loyal kepada produk tersebut. Bisnis yang digeluti ini akan menjadi sangat menguntungkan di negara dimana masyarakatnya mayoritas adalah seorang muslim seperti di Indonesia. Produsen yang belum atau tidak memiliki sertifikasi jaminan halal menjadi kurang di minati oleh konsumen (Kinanti et al., 2020)

Meskipun beberapa produsen dalam penelitian ini merasa belum mampu untuk melakukan sertifikasi halal, secara umum pada industri UMKM terjadi peningkatan dalam proses pengurusan sertifikasi jaminan halal setiap tahunnya yakni pada tahun 2017 sebanyak 9\% dan peningkatan besar terjadi pada tahun 2018 yakni 53\% produk UMKM yang sudah tersertifikasi halal (Kinanti et al., 2020).

Titik kritis halal pada suatu produk digunakan sebagai alat untuk mengendalikan adanya risiko produk pangan olahan tidak halal. Kesalahan pada proses produksi berupa tidak diterapkannya beberapa faktor seperti proses produksi yang benar, adanya human error, peralatan yang digunakan dan lingkungan kerja yang tidak sesuai dengan pedoman pada Sistem Jaminan Halal (Sholichah et al., 2017). Hal tersebut sejalan dengan penelitian yang 
dilakukan Aniqoh \& Hanastiana (2020), yang menyatakan bahwa makanan halal dapat menjadi tidak halal jika diolah dengan cara yang tidak halal.

Peluang ekonomi dapat dimaksimalkan dengan beberapa cara yaitu dengan kontrol kualitas makanan, inovasi produk, perluasan pasar, dan promosi. Menurut Sarijani (2015), inovasi produk dengan menciptakan menu baru dengan kualitas hasil yang maksimal merupakan salah satu cara mengembangkan produk dan bisnis kuliner. Selain itu, pemanfaatan teknologi informasi berupa e-commerce dapat memaksimalkan perluasan pasar dan promosi untuk menambah penghasilan (Irsad Adriyanto, 2018). Dalam jual beli online juga terdapat sistem yang disebut dengan pre-order dimana dengan sistem ini produsen dapat memperkirakan jumlah produksi dan meminimalisasi produk sisa yang menimbulkan kerugian.

Lebih lanjut, peluang juga dapat dimaksimalkan dengan manajemen komplain yang baik. Kesalahan atau kegagalan dalam memenuhi kebutuhan dan ekspektasi pelanggan merupakan sesuatu yang umum dalam bisnis dan tidak dapat dihindari sehingga memicu munculnya ketidakpuasan dan komplain. Dalam hal ini, manajemen komplain merupakan sebuah alat yang efisien dan efektif dalam menjaga hubungan kepada konsumen. Selain permohonan maaf, konsumen umumnya mengajukan ganti rugi berupa pengembalian uang, penggantian barang atau kompensasi. Secara umum, konsumen memberikan reaksi yang postif dengan pelayanan komplain yang ramah dan sopan (Kumar \& Kaur, 2020).

Risiko keamanan dan kehalalan pangan dapat diminimalkan dengan kolaborasi antara produsen, konsumen dan pemerintah. Dalam mengelola keamanan pangan dikenal dengan istilah 3 pilar yaitu produsen yang memproduksi pangan, pemerintah yang melakukan fungsi pengawasan dan konsumen yang cerdas dalam memilih produk yang dikonsumsinya (BPOM Aceh (2020) \& Lestari (2015).

Dalam memaksimalkan fungsi pengawasan pemerintah, produsen juga diharapkan berperan aktif untuk mendaftarkan usaha dan bergabung dalam organisasi UMKM atau organisasi pendukung sertifikasi jaminan halal untuk mendapatkan pendampingan dalam proses sertifikasi, baik sertifikasi keamanan pangan maupun sertifikasi jaminan halal.

Selain itu, dengan tingginya kepercayaan konsumen terhadap aplikasi agregator makanan, diharapkan pemerintah juga melakukaan koordinasi terkait standar keamanan dan kehalalan produk pangan yang dapat diakses melalui aplikasi tersebut. Hal tersebut dikarenakan banyaknya penjual dalam jasan pesan antar makanan merupakan usaha mikro informal, termasuk pengusaha rumah tangga yang cenderung memiliki pengetahuan yang rendah dan praktik penanganan makanan yang buruk (Aprilianti \& Amanta, 2020).

\section{Kesimpulan}

Industri makanan skala rumah tangga dengan sistem online memberikan dampak positif bagi pemenuhan kebutuhan konsumen, penguatan ekonomi rumah tangga, peningkatan peluang usaha, dan pemberdayaan masyarakat sekitar lingkungan usaha. Risiko kehalalan dan keamanan pangan yang muncul dalam produksi makanan skala rumah tangga muncul karena masih kurangnya pengetahuan produsen, keterbatasan sumberdaya, dan produk yang dihasilkan belum tersertifikasi, meskipun produsen telah mengupayakan untuk memaksimalkan keamanan dan kehalalan produk. 
Hasil penelitian ini selanjutnya juga memberikan gambaran berbagai strategi yang dapat diterapkan oleh UMKM pangan untuk meminimalisir resiko yaitu dengan membeli bahan baku yang telah teregistrasi BPOM dan atau supplier bersertifikat halal. Lebih lanjut potensi UMKM dapat dioptimalkan dengan inovasi produk, menerapkan sistem reseller, dan bergabung pada aggregator jasa makanan. Potensi kerugian dapat diminimalisir dengan sistem pre-order $(P O)$.

Hal tersebut diatas menekankan perlunya edukasi dan pendampingan sertifikasi pangan halal dan aman yang berkelanjutan bagi produsen, serta edukasi dan promosi pemilihan pangan halal dan aman bagi konsumen melalui peran serta pemerintah dan institusi terkait.

\section{Ucapan Terima Kasih}

Terimakasih kami ucapkan kepada pihak-pihak yang telah bersedia menjadi narasumber penelitian kami, dan juga kepada tim penelitian yang telah bekerjasama dengan sangat baik untuk menyelesaikan penelitian ini.

\section{Daftar Pustaka}

Achmad, Z. A., Azhari, T. Z., Esfandiar, W. N., Nuryaningrum, N., Syifana, A. F. D., \& Cahyaningrum, I. (2020). Pemanfaatan Media Sosial Dalam Pemasaran Produk Umkm Di Kelurahan Sidokumpul, Kabupaten Gresik. Jurnal Ilmu Komunikasi, 10(1), 15. http://jurnalfdk.uinsby.ac.id/index.php/JIK\%0APEMANFAATAN

Akim, Konety, N., Purnama, C., \& Adilla, M. H. (2018). The Understanding of Usaha Mikro, Kecil dan Menengah (UMKM) in Jatinangor on the Obligation of Halal Certification on Food Products. Kumawula: Jurnal Pengabdian Kepada Masyarakat, 1(1), 31-49. http://jurnal.unpad.ac.id/kumawula/index

Aniqoh, N. A. F. A., \& Hanastiana, M. R. (2020). Halal Food Industry: Challenges and Opportunities in Europe. Journal of Digital Marketing and Halal Industry, 2(1), 43. https://doi.org/10.21580/jdmhi.2020.2.1.5799

Aprilianti, I., \& Amanta, F. (2020). Makalah Kebijakan No.28: Memajukan Keamanan Pangan pada Layanan Pesan Antar Makanan Daring di Indonesia (Issue 28). https://repository.cips-indonesia.org/publications/324009/memajukan-keamananpangan-pada-layanan-pesan-antar-makanan-daring-di-indonesia

BPOM Aceh. (2020). Mencerdaskan Pelaku Usaha Pangan dan Konsumen, Kunci Keamanan Pangan. Balai POM Banda Aceh. https://www.pom.go.id/new/view/more/berita/19912/Mencerdaskan-Pelaku-UsahaPangan-dan-Konsumen--Kunci-Keamanan-Pangan.html

Chaudry, M. M., \& Riaz, M. N. (2014). Safety of Food and Beverages: Halal Food Requirements. In Encyclopedia of Food Safety (Vol. 3). Elsevier Ltd. https://doi.org/10.1016/B978-0-12-378612-8.00400-5

Farhan, A. (2019). Pelaksanaan Sertifikasi Halal Lppom Mui Terhadap Produk Usaha Mikro, Kecil Dan Menengah (Umkm) (Studi Lppom Mui Provinsi Bengkulu). Manhaj: Jurnal Penelitian Dan Pengabdian Masyarakat, 3(1), 1. https://doi.org/10.29300/mjppm.v3i1.2340 
Irsad Adriyanto. (2018). Penguatan Daya Saing Usaha Mikro Kecil Menengah Melalui ECommerce. Bisnis, 6(2), 1-8.

Kinanti, B. A., Pujianto, T., \& Kastaman, R. (2020). Analisis Titik Kritis Halal Pada Proses Produksi di Komunitas UKM Aksara Cimahi Menggunakan Failure Mode Effect Analysis (FMEA). Jurnal Ekonomi Pertanian Dan Agribisnis (JEPA), 4(4), 738-751. https://doi.org/10.21776/ub.jepa.2020.004.04.04

Kumar, A., \& Kaur, A. (2020). Complaint management-review and additional insights. International Journal of Scientific and Technology Research, 9(2), 1501-1509.

Lestari, T. R. P. (2015). Kewaspadaan terhadap Pangan yang Tidak Aman Dikonsumsi. Info Singkat Kesejahteraan Sosial, VII(08), 4.

Manayang, Y., Joseph, W. B. S., \& Sumampouw, O. J. (2018). Higiene dan Sanitasi Industri Pangan Rumah Tangga di Wilayah Kerja Puskesmas Paniki Bawah. KESMAS, 7(5). https://ejournal.unsrat.ac.id/index.php/kesmas/article/viewFile/22514/22205

Putra, K. A. D., Hidayatullah, F., \& Farida, N. (2020). Mediatisasi Layanan Pesan Antar Makanan Di Indonesia Melalui Aplikasi Go-Food. Islamic Communication Journal, 5(1), 114. https://doi.org/10.21580/icj.2020.5.1.5416

R. Pritanova, P., Muhandri, T., \& Nurjanah, S. (2020). Karakteristik dan Pemenuhan CPPOB Pelaku UMKM Online Produk Olahan Beku Daging Sapi dan Ayam di DKI Jakarta. Jurnal Ilmu Produksi Dan Teknologi Hasil Peternakan, 8(3), 102108. https://doi.org/10.29244/jipthp.8.3.102-108

Sarijani, E. (2015). Peran Kreativitas Dan Inovasi Pelaku Usaha dalam Diversifikasi Produk Kuliner Kedai Steak \& Chicken di Kabupaten Magetan Tahun 2014. In Universitas Sebelas Maret. Universitas Sebelas Maret.

Sholichah, W., Vanany, I., Soeprijanto, A., Anwar, M. K., \& Fatmawati, L. (2017). Analisis Risiko Makanan Halal Di Restoran Menggunakan Metode Failure Mode and Effect Analysis. Jurnal Ilmiah Teknik Industri, 16(2), 150. https://doi.org/10.23917/jiti.v16i2.4941

Sugiri, D. (2020). Menyelamatkan Usaha Mikro , Kecil dan Menengah dari Dampak Pandemi Menyelamatkan Usaha Mikro, Kecil dan Menengah dari Dampak Pandemi Covid-19. August. https://doi.org/10.32639/fokusbisnis.v19i1.575

WHO \& FAO. (2020). COVID-19 dan Keamanan Pangan: Panduan untuk otoritas yang berwenang atas sistem pengawasan keamanan pangan nasional: Panduan Interim (Issue April). https://creativecommons.org/licenses/by-nc- sa/3.0/igo/

Yunita, H. I. D. (2018). Studi Tentang Peluang dan Tantangan Industri Pangan Halal Terhadap Perekonomian di Indonesia.

Zhao, Y., \& Bacao, F. (2020). What Factors Determining Customer Continuingly Using Food Delivery Apps During 2019 Novel Coronavirus Pandemic Period? International Journal of Hospitality Management, 91(January), 12. 